\title{
Review Artikel: Pemanfatan Limbah Organik Pasar Sebagai Prekursor Budidaya Lawi-Lawi Caulerpa lentillifera
}

\author{
Utilization of Market Organic Waste As Precursor of Culture Caulerpa Lentillifera
}

\author{
Renal $^{1^{*}}$, Adyatma Ridwan ${ }^{2}$, Irpan Ramadhan $^{3}$, Erni Indrawati ${ }^{4}$ \\ *E-mail: renal.aquaculture@gmail.com \\ ${ }^{1,4}$ Program Studi Budidaya Perairan, Fakultas Pertanian, Universitas Bosowa \\ ${ }^{2}$ Fakultas Teknik, Universitas Bosowa \\ ${ }^{3}$ Fakultas Pertanian, Universitas Bosowa
}

Diterima: 01 Mei 2021 / Disetujui: 02 Agustus 2021

\begin{abstract}
ABSTRAK
Kebutuhan rumput laut dalam pasar domestik dan pasar internasional terus meningkat sesuai dengan data KKP pada tahun 2020, total produksi rumput laut pada tahun 2018 sebesar 213.422 ton, pada tahun 2019 sebesar 9.900.000 ton. Salah satu rumput laut yang memiliki prospek pemasaran yang cukup luas adalah lawi-lawi. Lawi-lawi Caulerpa lentillifera) merupakan spesies rumput laut hijau yang biasa dikenal dengan sebutan anggur laut dan tersebar di beberapa lautan tropis dan subtropis. Tujuan dari kegiatan ini adalah (1) melakukan kajian literatur budidaya $C$. lentillifera di tambak dan (2) melakukan kajian peningkatan produktivitas tambak dengan memanfaatkan limbah organik sebagai sumber hara tambak. Metode yang digunakan dalam pelaksanaan kegiatan ini adalah melakukan literatur review, yaitu sebuah pencarian literatur baik nasional maupun internasional yang dilakukan dengan mereview jurnal, skripsi online dan buku. Berdasarkan hasil review dari 16 kajian yang didapat dari berbagai sumber, diantaranya 16 Jurnal (11 Jurnal Nasional dan 5 Jurnal Internasonal), 2 Skripsi Online dan 2 Buku didapatkan bahwa ada beberapa hal yang mempengaruhi pertumbuhan $C$. lentillifera yaitu, penggunaan zat pengatur tumbuh, bobot awal yang berbeda, salinitas dan jenis substrat dasar, ketersediaan unsur-unsur hara di tanah dan air, serta kedalaman yang berbeda
\end{abstract}

Kata Kunci: Lawi Lawi, Caulerpa, Tambak, Limbah Organik

\begin{abstract}
The need for seaweed in the domestic market and the international market continues to increase according to KKP data in 2020, the total seaweed production in 2018 is 213,422 tons, in 2019 it is 9,900,000 tons. One of the seaweeds that has broad marketing prospects is lawi-lawi. Lawilawi Caulerpa lentillifera) is a species of green seaweed commonly known as sea grape and is distributed in several tropical and subtropical oceans. The objectives of this activity were (1) to study the literature on C. lentillifera cultivation in ponds and (2) to study the increase in pond productivity by utilizing organic waste as a source of pond nutrients. The method used in the implementation of this activity is to conduct a literature review, which is a literature search, both national and international, which is carried out by reviewing journals, online theses and books. Based on the results of reviews from 16 studies obtained from various sources, including 13 journals (8 National Journals and 5 International Journals), 1 Online Thesis and 1 Book, it was found that there were several things that influenced the growth of C. lentillifera, namely, the use of growth regulators, weight different bases, salinity and type of base substrate, availability of nutrients in soil and water, and different depths.
\end{abstract}

Keywords: Caulerpa lentillifera, Ponds, Growth, Organic Fertilizer 


\section{A. PENDAHULUAN}

Kebutuhan rumput laut dalam pasar domestik dan pasar internasional terus meningkat sesuai dengan data KKP (2020), total produksi rumput laut pada tahun 2018 sebesar 213.422 ton, pada tahun 2019 sebesar 9.900 .000 ton. Produksi rumput laut nasional di tahun 2020 ditargetkan mencapai angka 10.990.000 ton. Dalam 4 tahun kedepan KKP juga menargetkan produksi rumput laut nasional tumbuh rata-rata 2,92\% dalam periode 2020-2024. Untuk mencapai target tersebut, maka diperlukan usaha budidaya rumput laut pada berbagai spesies.

Lawi-lawi (Caulerpa lentillifera) merupakan salah satu spesies rumput laut hijau yang biasa dikenal dengan sebutan anggur laut dan tersebar di beberapa lautan tropis dan subtropis. Tumbuhan ini dapat dikonsumsi secara langsung baik dalam bentuk salad, lalap, sushi, diurap dengan bumbu kelapa, sebagai campuran pecel. C. lentillifera telah menemukan pasar yang besar di Tiongkok dan di beberapa bagian Tiongkok seperti Fujian, Qingdao, dan Beihai (Long et al., 2020). Dengan adanya serapan pasar yang cukup luas, C. lentillifera sangat berpotensi untuk dijadikan sebagai komoditas alternatif. Akan tetapi, sampai saat ini $C$. lentillifera masih tersedia dalam jumlah yang sangat terbatas dan musiman, karena bergantung pada alam dan hanya dapat ditemukan di beberapa perairan tertentu sehingga dibutukan kajian dan teknik budidaya yang tepat untuk menunjang kontiunitas produksinya.

Selama ini, usaha budidaya rumput laut yang dilakukan oleh para pembudidaya di tambak, umumnya menggunakan pupuk anorganik sebagai penyuplai unsur hara. Namun pupuk tersebut memiliki harga yang relatif mahal dan mengakibatkan terjadinya kejenuhan pada tanah dasar tambak, sehingga unsur-unsur esensial yang diperlukan untuk pertumbuhan rumput laut tidak tersedia. Salah satu upaya yang dapat dilakukan untuk memperbaiki produktivitas tambak adalah dengan penggunaan pupuk padat dari limbah organik pasar. Kandungan zat hara pada pupuk organik padat terdiri dari karbon $8,2 \%$, nitrogen $0,09 \%$, fosfor $0,36 \%$ dan kalium 0,81\% (Suryono, 2014 dalam Nurjannah, 2019).

$$
\text { Penumpukan limbah organik }
$$
tentunya akan menimbulkan degradasi kebersihan lingkungan karena mengeluarkan gas metan yang menyebabkan global warming, gas ini memiliki daya rusak 23 kali lebih kuat 
dari karbon (Banowati, 2011). Sehingga pengolahan limbah organik menjadi pupuk organik padat sangat tepat untuk menjaga kebersihan lingkungan dan memperbaiki produktivitas tambak. Manfaat bahan organik secara fisik memperbaiki struktur dan meningkatkan kapasitas tanah menyimpan air. Secara kimiawi meningkatkan daya sanggah tanah perhadap perubahan $\mathrm{pH}$, meningkatkan kapasitas tukar kation, menurunkan fiksasi $\mathrm{P}$ dan sebagai reservoir unsur hara sekunder dan mikro (Sufianto, 2014).

Tujuan dari kegiatan ini adalah melakukan kajian literatur budidaya $C$. lentillifera di tambak dan melakukan kajian peningkatan produktivitas tambak dengan memanfaatkan limbah organik sebagai sumber hara tambak.

\section{B. METODE PELAKSANAAN}

Metode yang digunakan dalam penulisan narrative review ini, adalah dengan melakukan literatur review, yaitu sebuah pencarian literatur baik nasional maupun internasional yang dilakukan dengan mereview buku, skripsi dan jurnal. Pelaksanaan literatur review dilakukan dari berbagai sumber dan dilakukan kombain yang selanjutnya dibuat narrative review.

\section{HASIL DAN PEMBAHASAN \\ 1. Review Penelitian Budidaya Rumput Laut}

Beberapa penelitian yang telah dilakukan oleh Ginting et al. (2015), Nurfebriani et al. (2015), Yuliyana et al. (2015), Darmawati (2015) dan Iskandar et al. (2015) memiliki masalah yang sama, yang diangkat sebagai poin pentiing dalam penelitiannya adalah permintaan akan rumput laut $C$. lentillifera terus meningkat, namun produksinya belum dapat tercukupi, hal ini dikarenakan produksinya yang bersifat musiman dan masih banyak mengandalkan hasil dari alam. Keadaan tersebut akan berakibat terhadap tidak adanya kontuinitas produksi Caulerpa sp setiap waktu. Produksi Caulerpa sp dapat ditingkatkan dengan adanya pengembangan teknologi budidaya. Hal ini dipertegas oleh Danesa (2016), bahwa meningkatnya permintaan konsumsi domestik dan perdagangan internasional telah menyebabkannya budidaya $C$. lentillifera secara komersial perlu dilakukan, hanya saja ketersediaan bibit $C$. lentillifera masih terbatas.

$$
\text { Saputra dan Manik (2017) }
$$

menekankan penelitian pada aspek bagaimana limbah budidaya yang dihasilkan dari sebuah budidaya ikan ataupun udang di tambak yang mengakibatkan pencemaran lingkungan 
perairan bila tidak segera ditangani dapat dimanfaatkan sebagai pupuk organik pada budidaya $C$. lentillifera. Sedangkan Putri (2017) menekankan masalah metode budidaya Caulerpa lentillifera masih banyak menghadapi kendala apabila dibudidayakan di tambak seperti cuaca buruk, hama dan penyakit. Tetapi apabila dibudidayakan pada wadah terkontrol kendala utama yaitu tidak adanya arus air yang dibutuhkan untuk pertumbuhan $C$. lentillifera dan pengontrolan kualitas air yang harus di lakukan secara rutin serta di dukung dengan adanya substrat yang baik yaitu pasir + pecahan karang. Hal ini dipertegas dengan penelitian Anh et al. (2020) bahwa $C$. lentillifera telah banyak dibudidayakan di tambak ataupun di keramba, namun prodktivitasnya masih sangat rendah disebabkan faktor cuaca yang berfluktuasi (tidak dapat dikendalikan).

Hui et al. (2015) lebih menekankan bahwa salinitas yang tinggi dapat mempengaruhi fotosintesis makroalga dengan menonaktifkan pusat reaksifotosistem II (PSII) dan menghambat transpor elektron. Nitrogen (N) dan fosfr (P) merupakan dua esensial nutrisi untuk pertumbuhan alga. Maka perlu dilakukan penelitian untuk menetukan salinitas yang baik pada budidaya $C$. lentillifera pada wadah terkontrol. Darmawati et al. (2016) menjabarkan bahwa penanaman rumput laut yang terlalu dalam akan menyebabkan kesulitan dalam pemeliharaan sedangkan apabila terlalu dangkal akan menyebabkan rumput laut terkena sinar matahari langsung. Tanduyan et al. (2013), Produksi $C$. lentillifera yang dibudidayakan di tambak selama 2 tahun terakhir mengalami penurunan akibat terjadinya degradasi lingkungan, sehingga $C$. lentillifera perlu diuji cobakan di laut untuk menentukan apakah spesies tersebut memiliki produksi yang lebih tinggi dibandingkan dengan di tambak.

Long et al. (2020) mengidentifikasi sebuah permasalahan, dengan adanya sedimen dasar dan penggunaan unsur hara yang berbeda dapat mempengaruhi akumulasi nutrisi $C$. lentillifera, sehingga perlu dilakukan penelitian untuk mengetahui penggunaan unsur hara yang tepat terhadap akumulasi nutrisi C. lentillifera. Novianti et al. (2015) menguraikan, petambak masih mengalami kesulitan budidaya $C$. lentillifera karena belum mengetahui bobot awal yang tepat, sehingga mengakibatkan kegagalan panen, karena tidak memperhitungkan berat awal penanaman akibatnya banyak 
tanaman yang patah atau hilang akibat tidak mampu menahan berat tanaman yang lain.

Permasalahan lain juga diindetifikasi pada spesies $C$. racemosa oleh beberapa peneliti seperti Pradika et al. (2020), Pemberian nutrien tambahan berupa pupuk dapat meningkatkan hasil produksi dari rumput laut $C$. racemosa, namun perlu diperhatikan bahwa penggunaannya harus memakai takaran yang tepat sehingga penyerapan dapat berlangsung secara maksimal. Penggunaan pupuk atau nutrien tambahan ini dapat efektif untuk meningkatkan produksi $C$. racemosa sehingga tidak bergantung lagi pada alam di musim. Sitorus et al. (2020) mengangkat permasalahan pengaruh intensitas cahaya yang berbeda untuk mengetahui intensitas cahaya yang optimal pada pertumbuhan C. racemosa. Yudasmara menekankan masalah, budidaya Caulerpa yang dilakukan di indonesia dilakukan dengan cara membenamkannya ke dalam substrat tanah seperti sistem menanam padi pada areal/lahan bekas tambak atau mengadopsi teknik budidaya seperti halnya di Jepang. Kondisi inilah yang menimbulkan permasalahan karena tidak disemua wilayah pesisir memiliki areal bekas tambak dan mahalnya biaya operasional teknologi budidaya dari Jepang tersebut. Oleh karena itu diperlukan suatu alih teknologi tepat guna untuk mengatasi permasalahan tersebut. Salah satunya dapat digunakan melalui rigid quadrant nets berbahan bambu. Istiana (2016) melakukan penelitian dengan mengangkat permasalahan, Caulerpa yang hidup di perairan laut memiliki ketersediaan unsur hara yang sangat terbatas, sehingga dalam budidaya Caulerpa membutuhkan kualitas cahaya dan nutrien yang cukup agar dapat melakukan proses fotosintesis serta dapat tumbuh dengan optimal. Nutrien seperti fosfat dan nitrat dibutuhkan sebagai bahan dasar komponen penyusun protein dan pembentukan klorofil saat melakukan fotosintesis. Adapun masalah yang ditekankan oleh Syamsuddin (2018), selama ini ketersediaan Caulerpa racemosa masih mengandalkan hasil dari alam dan keberadaannya tidak menentu (berdasarkan musim). Permasalahan ini hampir sama dengan beberapa permasalahan pada Caulerpa lentillifera.

\section{Analisis Terhadap Persamaan dan Perbedaan dari Setiap Penelitian}

Penurunan produksi udang yang disebabkan oleh wabah penyakit, mengakibatkan banyak tambak yang terlantar dan tidak produktif. Petambak 
membiarkan lahannya kosong begitu saja, padahal tambak tersebut dapat digunakan untuk membudidayakan Lawi-lawi (Caulerpa lentillifera). Usaha budidaya rumput laut yang dilakukan oleh para pembudidaya di tambak, umumnya menggunakan pupuk anorganik sebagai penyuplai unsur hara. Namun pupuk tersebut memiliki harga yang relatif mahal dan mengakibatkan terjadinya kejenuhan pada tanah dasar tambak, sehingga unsur-unsur esensial yang diperlukan untuk pertumbuhan rumput laut tidak tersedia. Namun, upaya yang dapat dilakukan untuk memperbaiki produktivitas tambak adalah dengan penggunaan pupuk padat dari limbah organik pasar.

Berdasarkan hasil penelitian yang telah dilakukan oleh Ginting et al. (2015), menunjukkan bahwa penggunaan pupuk organik cair pada dosis $3,5 \mathrm{~mL}$ yang dibudidayakan di wadah terkontrol menunjukkan nilai laju pertumbuhan spesifik sebesar 3,29\%/hari, hal ini diduga karena terdapat banyak nutrien yang dapat diserap, sedangkan tanpa perendaman pupuk organik cair menunjukkan pertumbuhan yang lebih rendah. Selain itu, penelitian dengan menggunakan perlakuan waktu perendaman yang berbeda menunjukkan lama perendaman 6 jam menghasilkan nilai laju pertumbuhan spesifik $(3.27 \pm 5.12 \% /$ hari $)$ yang terbaik. Sedangkan perlakuan tanpa perendaman pupuk menghasilkan nilai pertumbuhan terendah dibandingkan dengan perlakuan yang diberi pupuk dengan laju pertumbuhan spesifik sebesar $1,2 \%$. Hal ini, diduga karena ketersediaan nutrien belum tercukupi untuk kebutuhan $C$. lentillifera, sehingga dengan penambahan pupuk akan memberikan hasil pertumbuhan yang baik (Nurfebriani $e t$ al., 2015). Pemberian pupuk limbah padat pada tambak udang dengan dosis $6 \mathrm{~g} / \mathrm{l}$ (Perlakuan C) memberikan pengaruh paling tinggi terhadap laju pertumbuhan (7,29 g/hari), kadar protein $(8,27 \%)$ serta kandungan klorofil-a $\quad(3,46 \quad \mathrm{mg} / \mathrm{l})$; klorofil-b $(7,41 \mathrm{mg} / \mathrm{l})$; total klorofil (16,08mg/l) pada Caulerpa lentillifera (Saputra dan Manik, 2017).

Hui et al. (2015), mengungkapkan bahwa $C$. lentillifera dapat bertahan hidup pada salinitas $20-45 \mathrm{ppt}$, apabila salintasnya kurang ataupun lebih dari angka tersebut maka akan mengalami pembusukan dalam tiga hari, dan secara bertahap memutih dan menjadi lunak. Hasil penelitian tersebut menunjukkan bahwa pertumbuhan optimal terdapat pada salinitas 35 ppt. Kemudian pada salinitas 20 dan 45 , hanya stolon yang 
beregenerasi dari cabang. Namun, cabang baru dengan ramuli tumbuh dari stolon pada salinitas 30-40. Hal ini berbeda dengan pernyataan Yuliyana et al. (2015), bahwa salinitas 30 ppt memiliki pertumbuhan tertinggi dan pada salinitas 20 ppt pertumbuhan eksplan lambat disebabkan oleh penyerapan nutrien tidak optimal akibat kondisi media kurang sesuai. C. lentillifera bertahan hidup pada salinitas berkisar antara 20-50 ppt, dapat berkembang pada kisaran 30-40 ppt. Pernyataan ini hampir sama dengan hasil kajian Suparman (2018), yang menyatakan $C$. lentillifera dapat tumbuh pada salinitas berkisar antara $20-35$ ppt dan pertumbuhan terbaik terdapat pada salinitas 30 ppt.

Anh et al. (2020) menginformasikan bahwa $C$. lentillifera dapat tumbuh pada kedalaman 60-100 cm dan kedalaman yang ideal terdapat pada kedalaman $80 \mathrm{~cm}$, semakin dalam perairan maka pertumbuhan $C$. lentillifera juga akan semakin baik. Hal ini sangat berbeda dengan hasil penelitian Darmawati et al. (2016) yang mendapatkan pertumbuhan mutlak tertinggi pada perlakuan A $(50 \mathrm{~cm})$ sebesar 197 gr. Disusul perlakuan B (100 $\mathrm{cm})$ sebesar 177.5 gr kemudian terendah perlakuan C $(150 \mathrm{~cm})$ sebesar 144.3 gr.
Adapun penelitian yang menggunakan perlakuan kedalaman yang berbeda tetapi diterapkan pada lawi-lawi jenis Caulerpa racemosa seperti yang dilakukan oleh Ismianti (2018), hasil pengukuran pertumbuhan relatif pada $C$. recemosa dengan lama pemeliharaan selama 40 hari didapatkan hasil tertinggi pada perlakuan D $(75 \mathrm{~cm})$ sebesar $13.874 \%$, sedangkan untuk pertumbuhan relatif paling rendah terdapat pada perlakuan $\mathrm{A}(0 \mathrm{~cm})$ dengan hasil sebesar $11.132 \%$. Dari perlakuan yang digunakan terdapat perlakuan yang tidak berbeda nyata yaitu pada perlakuan B $(25 \mathrm{~cm})$ dengan hasil sebesar $12.736 \%$ dan pada pelakuan $\mathrm{C}(50 \mathrm{~cm})$ dengan hasil sebesar $13.024 \%$. Hasil penelitian ini hampir sama dengan penerapan pada C. racemosa, yang mendapatkan hasil semakin dalam perairan maka pertumbuhan $C$. lentillifera juga akan semakin baik,

Sitorus et al. (2020) melakukan penelitian pada lawi-lawi jenis Caulerpa racemosa yang dengan melihat pengaruh intensitas cahaya, hasil penelitian tersebut menunjukkan bahwa perlakuan A $( \pm 1000$ lux) menghasilkan laju pertumbuhan yang lebih baik $(1,29 \pm 0,04 \%$ berat/hari $)$ dibandingkan dengan perlakuan B (1,12 \pm $0,06 \%$ berat/hari) dan perlakuan C $(0,4 \pm$ $0,09 \%$ per hari) karena cahaya yang 
diterima pada perlakuan A lebih besar dibandingkan dengan perlakuan $\mathrm{B}$ dan $\mathrm{C}$. Hal ini diduga pada konsentrasi tersebut faktor lingkungan terutama intensitas cahaya yang dibutuhkan $C$. racemosa untuk pertumbuhan lebih mendekati kondisi di alam.

Penelitian C. lentillifera juga telah dilakukan dengan penerapan 2 metode yaitu metode penaburan dan metode nampan oleh Danesa (2016), yang menunjukkan bahwa penggunaan substrat (metode penaburan) menghasilkan nilai pertumbuhan pada berat akhir yang lebih baik dengan masa pemeliharaan 60 hari yaitu sebesar 1030 gr (888\%) dibanding penggunaan baki (metode nampan) sebesar 649 (58\%). Penelitian serupa juga telah dilakukan oleh Tanduyan et al. (2013), yang mendapatkan rata-rata laju pertumbuhan $C$. lentillifera pada 3 stasiun dengan menggunakan 4 metode budidaya yang berbeda yaitu stasiun 1 (Substrat Berlumpur), stasiun 2 (Substrat Berbatu) dan stasiun 3 (Sandy Bottom). Hal ini menunjukkan bahwa pada stasiun 2 (Substrat Berbatu) memilki nilai pertumbuhan yang lebih baik, dengan metode keramba plastik kasa mendapat nilai tertinggi $(608,3 \mathrm{~g})$ dan terendah pada metode sangkar kasa nilon (248,3 g), begitupun pada stasuin 1 dan 3 .
Hal ini sesuai dengan penelitian yang dilakukan oleh Long et al. (2020), yang melaporkan bahwa adanya substrat atau sedimen dasar dapat mendorong atau menekan pertumbuhan anggur laut, yang dapat mempengaruhi akumulasi bahan organik. Selain itu, budidaya anggur laut dengan adanya substrat atau sedimen dasar memperoleh lebih banyak unsur mineral dari lingkungan dibanding anggur laut yang dibudidayakan tanpa sedimen dasar. Pernyataan tersebut juga didukung oleh hasil kajian Putri (2017), yang menggunakan subtrat atau sedimen dasar (Pasir 25\% + Pecahan Karang 75\%) mendapat nilai pertumbuhan tertinggi yaitu $80,12 \mathrm{gr} \pm 14,44 \%$. Besarnya pertumbuha $\mathrm{n}$ mutlak maupun $S G R$ tersebut, diduga karena $C$. lentillifera memperoleh suplai nutrien yang banyak dalam mempercepat pertumbuhannya.

Adapun penelitian mengenai subsrat dasar juga dilakukan oleh Syamsuddin (2018) tetapi menggunakan jenis Caulerpa racemosa, Laju pertumbuhan harian tertinggi $C$. racemosa 33,33 \pm $0,27 \%$ dan hasil pertumbuhan harian terendah terdapat pada substrat pasir + lumpur $1,38 \pm 0,14 \%$. Sedangkan pertumbuhan mutlak tertinggi terdapat pada substrat pecahan karang sebesar $116,00 \pm 14,67$ gr dan yang terendah 
terdapat pada substrat pasir + lumpur sebesar $35,25 \pm 4,43$ gr. Pertumbuhan harian dan mutlak tertinggi $C$. racemosa yang ditumbuhkan pada substrat pecahan karang, baik secara tunggal ataupun dicampur dengan substrat lainnya. Begitupun dengan hasil temuan sebelumnya yang menyatakan bahwa tipe substrat yang paling baik bagi pertumbuhan rumput laut adalah campuran karang dan pasir atau pecahan karang.

Jarak tanam juga berpengaruh terhadap pertumbuhan $C$. lentillifera, berdasarkan hasil penelitian Darmawati (2015), Rata-rata laju pertumbuhan harian perlakuan B jarak tanam $30 \mathrm{~cm}(3,80 \%)$, lebih tinggi dibandingkan dengan laju pertumbuhan harian pada perlakuan $\mathrm{C}$ jarak tanam $40 \mathrm{~cm}(3,25 \%)$, dan pada perlakuan A jarak tanam $20 \mathrm{~cm}(3,23 \%)$.

Selain beberapa faktor diatas, Dinyatakan oleh Iskandar et al. (2015) bahwa pertumbuhan relatif perlakuan $\mathrm{A}$ dengan bobot awal $50 \mathrm{~g}$ memiliki pertumbuhan yang lebih baik dibandingkan dengan perlakuan B (75 g), C (100 g), dan D (125 g). Diduga rendahnya bobot lawi-lawi pada awal penanaman menyebabkan penyerapan unsur hara dalam proses metabolisme rumput laut. Sependapat Novianti et al.
(2015) bahwa laju pertumbuhan harian (SGR) C. lentillifera dengan perlakuan A bobot (50 g) memiliki pertumbuhan yang paling tinggi. Nilai dari masing-masing laju pertumbuhan harian setiap perlakuannya berkisar antara 1.85 $0.11 \%$ /hari hingga $2.66 \pm 0.10 \% /$ hari. Tingginya nilai SGR pada perlakuan A diduga karena bobot yang digunakan pada awal tanam lebih rendah dibandingkan dengan perlakuan lainnya. Semakin rendah bobot rumput laut yang ditanam maka akan semakin baik pertumbuhannya.

Penelitian terdahulu juga telah dilakukan oleh Pradhika et al. (2019) mengkombinasikan pupuk organik cair dan padat sebagai perlakuan yang diterapkan pada lawi-lawi jenis Caulerpa racemosa dan dibudidayakan pada wadah terkontrol, hasil penelitian tersebut menunjukkan bahwa Perlakuan C (Pupuk Padat + Cair) mendapatkan berat basah tertinggi, hal ini diduga karena rumput laut mendapat nutrien yang cukup dan seimbang untuk pertumbuhannya, unsur makro yang didapat dari pupuk. Perlakuan A (Pupuk Padat) mendapatkan hasil berat basah paling rendah pada saat akhir pengukuran sebesar 11,5 gram. Hal ini diduga karena tidak memenuhi nutrien yang seimbang untuk $C$. racemosa. Selain 
itu, adapun penelitian yang dilakukan oleh Istiana (2016) yang mengkaji penggunaan komposisi pupuk NPK pada lawi-lawi jenis Caulerpa racemosa, berdasarkan hasil penelitian tersebut menunjukkan bahwa pertumbuhan terbaik ditunjukkan perlakuan dosis 1 NPK (1:1:1) tanpa aerasi, dengan rerata panjang stolon akhir $\pm 351 \mathrm{~cm}$, jumlah ramuli 38 buah dan rerata berat basah akhir 34,1 gr. Pertumbuhan terendah dihasilkan oleh perlakuan dosis NPK yang sama menggunakan aerasi dengan rerata panjang stolon 117,06, jumlah ramuli 11 buah dan rerata berat basah akhir 12,18 gr. Namun penerapan penambahan pupuk organik padat dari limbah organik pasar pada lawi-lawi jenis Caulerpa lentillifera menggunakan bobot awal berbeda yang dibudidayakan di tambak belum ada dilaporkan.

Berdasarkan beberapa pernyataan di atas, diduga pertumbuhan $C$. lentillifera pada berat terendah (50 gr) dengan pemberian pupuk organik padat dari limbah organik pasar, akan menunjukan pertumbuhan lebih tinggi dibandingkan berat (75 gr) dan seterusnya, sehingga produktivitas tambak akan lebih baik dari sebelumnya.

\section{KESIMPULAN DAN SARAN}

Beberapa hal yang mempengaruhi pertumbuhan $C$. lentillifera berdasarkan hasil kajian literatur adalah dengan penggunaan zat pengatur tumbuh, bobot awal yang berbeda, salinitas dan jenis substrat dasar serta kedalaman yang berbeda.

\section{E. UCAPAN TERIMA KASIH}

Penulis mengucapkan terimakasih kepada Kementerian Riset Teknologi dan Pendidikan Tinggi (KEMRISTEKDIKTI) atas pendanaan yang diberikan melalui kegiatan Program Kreativitas Mahasiswa (PKM) sehingga kegiatan ini dapat berjalan dengan baik.

\section{DAFTAR PUSTAKA}

Anh, N.T.N., Thong, L.V., Lam, N.P., Lien, T.T.K. and Hoa, N.V. 2020. Effects of water levels and water exchange rates on growth and production of sea grape Caulerpa lentillifera J. Agardh 1837. International Journal of Fisheries and Aquatic Studies. 8 (3):211-216.

Banowati. 2011. Pengelolaan Sampah Berbasis Komunitas Untuk Konservasi Lingkungan. Skripsi. Fakultas Teknik Universitas Diponegoro, Semarang.

Budi, S., \& Mardiana, M. (2021). Peningkatan Pertumbuhan Dan Kecerahan Warna Ikan Mas Koi Cyprinus Carpio Dengan Pemanfaatan Tepung Wortel Dalam Pakan. Journal of Aquaculture and Environment, 3(2), 46-50. 
Danesa, M.S.R. 2016. Cultivation of C.lentillifera Using Tray and Sowing Methods in Brackishwater Pond. Environmental Sciences. 4 (1):23- 29.

Darmawati, Rahmi, Jayadi, E.A. 2016. Optimasi Jarak Tanam Terhadap Pertumbuhan Caulerpa sp di Perairan Laguruda Kabaupaten Takalar. Jurnal Ilmu Perikanan Octopus. 5 (1):435-442.

Darmawati. 2015. Optimasi Jarak Tanam Terhadap Pertumbuhan Caulerpa sp di Perairan Laguruda Kab. Takalar. Jurnal Ilmu Perikanan Octopus. 4 (1):337- 334.

Ginting, E.S, Rejeki, S. dan Susilowati, T. 2015. Pengaruh Perendaman Pupuk Organik Cair Dengan Dosis yang Berbeda Terhadap Pertumbuhan Caulerpa lentillifera. Journal of Aquaculture Management and Technology. 4 (4):82-87.

Hadijah, H., Mardiana, M., Indrawati, E., Budi, S., \& Zainuddin, Z. (2021). The use of artificial feed in Haliotis squamata farming in submerged cage culture system at Lae-Lae island, Makassar. Revista Ambiente \& Água, 16.

Hui, G., Jianting, Y., Zhongmin, S. and Delin, D. 2015. Effects of Salinity and Nutrients on The Growth and Chlorophyll Fluorescence of Caulerpa lentillifera. Chinese Journal of Oceanology and Limnology. 33 (2):410-418.

Iskandar, S.N., Rejeki, S. dan Susilowati, T. 2015. Pengaruh Bobot Awal yang Berbeda Terhadap Pertumbuhan Caulerpa lentillifera yang Dibudidayakan Dengan Metode Longline di Tambak Bandengan, Jepara. Journal of Aquaculture Management and Technology. 4 (2) : 21-27.

Ismianti, J., Diniarti, N. dan Ghazali, M. 2018. Pengaruh Kedalaman
Terhadap Pertumbuhan Anggur Laut (Caulerpa racemosa) Dengan Metode Longline di Desa Tanjung Bele Kecamatan Moyo Hilir Kabupaten Sumbawa. Skripsi. Fakultas Ilmu Kelautan dan Perikanan Universitas Mataram, Mataram.

Istiana, A. 2016. Pengaruh Variasi N, P dan K Terhadap Laju Pertumbuhan Anggur Laut (Caulerpa racemosa) pada Media Terkontrol. Skripsi. Fakultas Sains dan Teknologi, Universitas Islam Negeri Sunan Kalijaaga. Yogyakarta.

Long H., Gu, X., Zhu, Z., Wang, C., Xia, X., Zhou, N., Liu, X. and Zhao, M. 2020. Effects of Bottom Sediment on the Accumulation of Nutrients In the Edible Green Seaweed Caulerpa lentillifera (Sea Grapes). Journal of Applied.

Phycology. 3 (2):705-716.

Novianti, D, Rejeki, S. dan Susilowati, T. 2015. Pengaruh Bobot Awal yang Berbeda Terhadap Pertum-buhan Rumput Laut Latoh (C. lentillifera) yang Dibudidaya di Dasar Tambak, Jepara. Journal of Aquaculture Management and Technology. 4 (4): 67 - 73.

Mambai, R. Y., Salam, S., \& Indrawati, E. (2020). Analisis Pengembangan Budidaya Rumput Laut (Euchema cottoni) di Perairan Kosiwo Kabupaten Yapen. Urban and Regional Studies Journal, 2(2), 6670 .

Nurfebriani D., Sri, R dan Lestari, L.W. 2015. Pengaruh Pemberian Pupuk Organik Cair Dengan Lama Perendaman yang Berbeda Terhadap Pertumbuhan Rumput Laut (Caulerpa lentillifera). Journal of Aquaculture Management and Technology. $4 \quad$ (4):88-94.

Numberi, Y., Budi, S., \& Salam, S. (2020). Analisis Oseanografi Dalam 
Mendukung Budidaya Rumput Laut (Eucheuma Cottonii) Di Teluk Sarawandori Distrik Kosiwo YapenPapua. Urban and Regional Studies Journal, 2(2), 71-75.

Nurjannah, N., Afdatullah, L., Abdullah, D.N., Jaya, F. dan Ifa., L. 2019. Pembuatan Pupuk Organik Padat dengan Cara Aerob. Journal of Chemical Proces Engineering. 4(2):90-96.

Pradhika, V.D., Suryono dan Sedjati, S. 2019. Pengaruh Penambahan Pupuk Padat dan Cair terhadap Pertumbuhan, Jumlah Klorofil dan Kadar Protein Caulerpa racemosa. Journal of Marine Research. 8 (3):269 - 276.

Putri, D.K. 2017. Pengaruh Komposisi Substrat Terhadap Pertumbuhan, Kandungan Karotenoid, Serat, dan Abu Anggur Laut (Caulerpa lentillifera J.Agardh, 1873) pada Wadah Terkontrol. Skripsi. Fakultas Perikanan dan Ilmu Kelautan, Universitas Hasanuddin. Makassar.

Saputra dan Manik, N.R.. 2017. Pemanfaatan Limbah Padat Tambak Udang Dalam Budidaya Caulerpa lentillifera. Journal of Aquaculture Management and Technology. 3 (1): 12-22.

Sitorus, E.R., Santosa, G.W. dan Pramesti, R. 2020. Pengaruh Rendahnya Intensitas Cahaya Terhadap Caulerpa racemosa (Forsskal) 1873 (Ulvophyceae :Caulerpaceae). Journal of Marine Research. 9 (1):13-17.

Sufianto. 2014. Analisis Mikroba pada Cairan sebagai Pupuk Cair Limbah Organik dan Aplikasinya Terhadap Tanaman Pakcoy (Brassica Chinensis L.). Jurnal Gamma. 9 (2):77-94.
Suparman. 2018. Cara Mudah Budidaya Rumput Laut Menyehatkan dan Menguntungkan. Pusaka baru press, Yogyakarta.

Syamsuddin, R. 2018. Rumput Laut Kumpulan Hasil Penelitian. Pijar Pres, Makassar.

Tanduyan, S.N., Gonzaga, R.B. and Bensig, V.D. 2013. Off Bottom Culture of $C$. lentillifera in Three Different Water Levels in the Marine Waters of San Francisco, Cebu, Philippines. Journal of Coral Reef Studies. 2 (4):123-132.

Yudasmara, G.A. 2014. Budidaya Anggur Laut (Caulerpa racemosa) Melalui Media Tanam Rigid Quadrant Nets Berbahan Bambu. Jurnal Sains dan Teknologi. 3 (2):468-473.

Yuliyana, A., Rejeki, S. dan Widowati, L. 2015. Pengaruh Salinitas Berbeda Terhadap Pertumbuhan $C$. lentillifera di Laboratorium Pengembangan Wilayah Pantai (LPWP)Jepara.Journal of Aquaculture Management and Technology.4(4):61-66.

Yusneri, A., \& Budi, S. (2021, May). Blue swimming crab (Portunus pelagicus) megalopa stage seed feed enrichment with beta carotene. In IOP Conference Series: Earth and Environmental Science (Vol. 763, No. 1, p. 012026). IOP Publishing. 